\title{
Absconsion from forensic psychiatric institutions: a review of the literature
}

\author{
Danielle Campagnolo ${ }^{1}$, Ivana Furimsky ${ }^{2,3}$, Gary A. Chaimowitz ${ }^{2,3}$
}

\author{
1 McMaster University, Health Sciences Program, \\ Hamilton, Canada \\ ${ }^{2}$ McMaster University, Department of Psychiatry and \\ Behavioural Neurosciences, Hamilton, Canada \\ 3 St. Joseph's Healthcare Hamilton, Forensic \\ Psychiatry Program, Hamilton, Canada
}

Background: Absconding from mental health units is referred to as a patient leaving without permission and can have significant consequences for the patient, family, community, and institution. The varying definitions of absconsion involve breaching security of an inpatient unit, accessing grounds or community without permission, gaining liberty during escorted leave or being absent for longer than permitted from authorized or trial leave. While considerable literature exists on absconsion from acute psychiatric units, there is a paucity of literature specific to forensic absconsions, despite inherent differences between patients and systems. Forensic patients are offenders who are found unfit to stand trial, or not criminally responsible on account of mental disorder. The literature indicates the absconding rate within the forensic population is expected to be low, based on the fact that the level of security in forensic units is higher than general psychiatric units. Despite the rates being considered low, the outcomes of absconding in this population can potentially be serious, thus the exploration of factors surrounding these incidents is essential. Purpose: To review the literature regarding absconsion from forensic psychiatric institutions. This review will identify potential risk factors and motivations of forensic patients that have absconded. Methods: Electronic database and hand searches were conducted to locate articles pertaining to absconding specific to forensic psychiatric institutions published from 1969-present. Search terms included "abscond", "escape", "AWOL", "runaway", "psychiatric inpatient", "forensic institution", \& variants. All full-text articles meeting inclusion \& exclusion criteria were appraised for qualitative themes, limitations, and assessed for risk of bias using appropriate CASP Checklists. The review is structured following the PRISMA checklist and framework. Results: A total of 19 articles meeting literature review criteria were identified. The majority of the articles were of retrospective case-control design $(n=12)$. Three systematic reviews were found on absconsion that included analyses from both forensic and general psychiatric populations. Definitions for absconding were omitted or varied making comparisons between studies difficult. Much research compared demographic, static and dynamic factors. History of previous absconsion, scores on validated risk-of-violence assessment tools, substance-use disorder, acute mental state, and socio-environmental factors were consistently noted as risk-factors. Four distinct motivations for absconding emerged: goaldirected, frustration/boredom, symptomatic, and accidental. Overall, the literature suggested forensic absconsion was a rare event of short duration with low risk to the public and few reoffending incidents. Conclusions: There is a paucity of literature on forensic absconsions. $A$ consistent definition of absconsion and use of standardized reporting protocols across forensic programs would be beneficial in order to be able to compare data on absconding events. Also, prospective studies should be undertaken to better understand the motivations and dynamic risk factors of forensic patients who have absconded and would help inform a forensic absconsion risk assessment protocol.

Key words

Abscond, escape, forensic, secure hospital, psychiatric inpatient, offender-patient

Acronyms

HCR-20- Historical Clinical Risk Management-20, LARALeave/Abscond Risk Assessment, PCL-R- Psychopathy Checklist-Revised, EMR-Electronic Medical Record

\section{Introduction}

Absconsion of patients from forensic mental health units can have significant consequences for the patient, hospital, and greater community [1-11]. Absconsion can be defined as an unauthorized leave of absence from mental health inpatient services. Within the literature, however there is no standard definition of 
absconsion used. Definitions can include instances of breaching the security of an inpatient unit, accessing hospital grounds or the community without permission, fleeing from staff while on community outings, being absent for longer than permitted, or failure to return from an authorized or trial leave [1-6,8,9,11-14]. Regardless of the circumstances surrounding the event, the potential for serious outcomes exists.

Absconsion from forensic mental health units can compromise a patient's safety and result in suicide or serious self-harm $[1,5,8,15]$ with the risk of suicide being elevated immediately upon return of the patient to the unit $[2,8,16]$. Substance and alcohol use are also commonly reported during absconding with over $50 \%$ of absconders in one study reporting use on leave $[2,4,7-9,11,14]$. There is risk of exposure to the environmental elements since many patients do not have a home to seek shelter $[1,15]$. Absconsions can lead to distrust in psychiatric services by families who expect the hospital to keep patients safe. The reputation of the forensic hospital and its processes can be put under scrutiny by a community expecting adequate management of patients who may pose a danger within a community or are at risk for violence [1-11,17]. In absconsions from forensic institutions, police are notified which may precipitate media attention, exacerbating both the situation and stigma $[2,5,18,19]$.

Within forensic psychiatric institutions, patients are under much higher security due to potential risk for violence $[1,13,17]$. This level of security may decrease overall rates of absconsion, however also results in a lack of autonomy related to treatment, heightened perceived stigma, and isolation of patients from the hospital and community $[1,13,20-22,24]$. Lengthy durations of stay in hospital in comparison to non-forensic patients is a unique source of stress, making forensic rehabilitation and motivations for absconsion more complex [4,6,9,11,21-24].

However, for nearly all forensic patients some form of leave is a fundamental part of their rehabilitation $[17,20,21,23]$. Clinical teams realize the risk of absconsion exists when granting this leave [23]. However, lack of evidence on absconsion specific to the forensic population, makes clinical decision-making and identifying patients at high risk of forensic absconding more difficult. The purpose of this literature review is to evaluate the state of literature in relation to absconsions from forensic mental health units. It will aim to identify risk factors and motivations highlighted in the literature that can help inform decisionmaking in granting leave.

\section{Methods}

Searches of electronic databases were conducted to locate articles pertaining to absconding specific to forensic mental health patients published from 1969present. The following databases were searched: Ovid, MEDLINE, PsychINFO, CINAHL, PubMed and Web of Science. A hand search was also conducted of Google Scholar, the Web, and relevant publications' reference lists. The following search terms were used with variants in parentheses: "Abscond" (absconding, absconder, absconded), "Escape", "Elope", "AWOL", "AWOP", "Runaway" (at large), "Psychiatric Inpatient" (Patient, Resident, Absconder, Offender, Offender-Patient), "Forensic Institution" (Special Hospital, High-Security Psychiatric Hospital, Forensic Hospital/Ward, Secure Hospital). Included publications were in English. Initially, the search timeframe was set from 2007 to present with November 20th, 2018 being the last date searched. However, due to the low quantity of articles $(n=10)$, the timeframe was adjusted to include relevant publications from 1969. The search excluded theses or other grey literature and only literature published in peer-reviewed journals was included. Full-text articles meeting criteria were appraised for qualitative themes, limitations, and assessed for bias using CASP Checklists [25]. The review was guided by the PRISMA checklist and Explanation and Elaboration document [26]. Figure 1 illustrates the different phases of the literature review. 


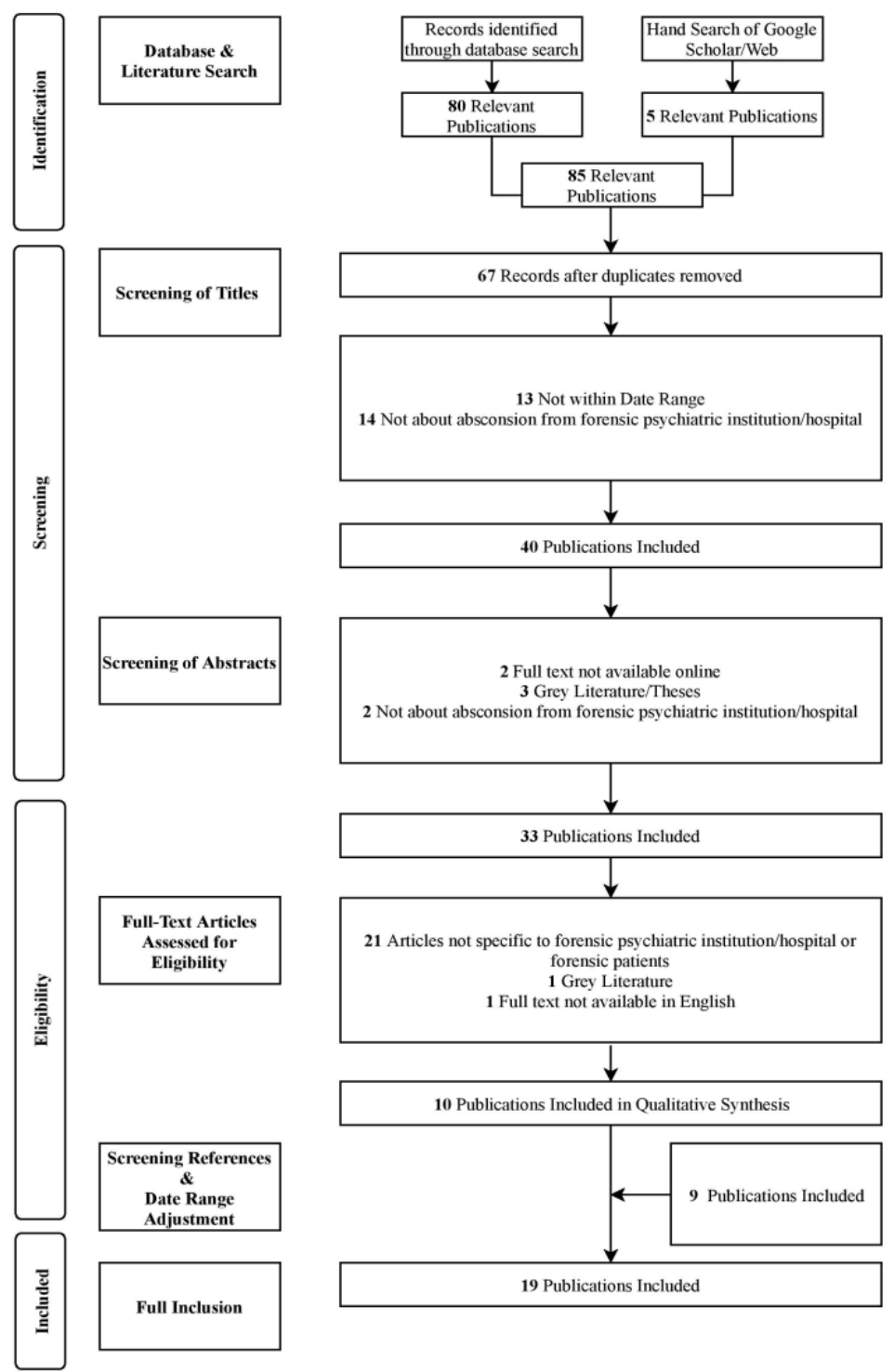

Figure 1. Literature Review Process

\section{Results}

A total of 19 full-text articles met the criteria for this literature review. The majority of the articles were published between 2009$2018[4,7-14,23]$. Eleven of the studies were conducted in the United Kingdom $[2,3,5,-7,12-14,19,23,28]$, three in the United States [10,18,27], three in Canada $[4,9,11]$, and two in Australia [1,8]. A summary of the characteristics and results of each study is included in Table 1. The majority $(n=12)$ were of retrospective design $[2-8,10,11,18,27,28]$. Only one included a prospective cohort following forensic psychiatric patients over a twoyear follow-up for absconding incidents [14]. Another included an A-B prospective study design evaluating the effectiveness of a risk-assessment tool [9].
Three systematic reviews were found on the subject of absconsion; all included articles from both forensic and general psychiatric institutions $[1,12,13]$. Remaining studies involved qualitative observation of clinician decision making, and a description of an absconsion protocol $[19,23]$.

\section{Definitions of Absconsion}

There was no consistent definition of absconding used within the literature on forensic mental health units (Table 1). 
Table 1. Study Characteristics (table formatted following Bowers et al., 1998 and according to Moher et al., 2009)

\begin{tabular}{|c|c|c|c|c|c|c|c|c|}
\hline Study & Place & Study Design & Population & $\begin{array}{l}\text { Comparison } \\
\text { Group }\end{array}$ & Intervention & Absconding Definition & Absconding Rates & Outcomes Analyzed \\
\hline $\begin{array}{l}\text { Morrow et al. } \\
1969\end{array}$ & USA & $\begin{array}{l}\text { Retrospective } \\
\text { Case-Control }\end{array}$ & $\begin{array}{l}\text { State maximum- } \\
\text { security building for } \\
\text { male psychiatric } \\
\text { offenders 1956-1966; } \\
40 \text { patients who } \\
\text { attempted to escape } \\
\text { from building }\end{array}$ & $\begin{array}{l}\text { Unselected } \\
\text { security-building } \\
\text { admissions over } 5 \\
\text { years, and to } 80 \\
\text { non-escapees }\end{array}$ & Chart Review & "Escape episode" & Not reported & $\begin{array}{l}\text { Characteristics of escape } \\
\text { behaviour, comparison of } \\
\text { escapees/non-escapee } \\
\text { groups on background } \\
\text { characteristics. Composite } \\
\text { scoring index developed }\end{array}$ \\
\hline $\begin{array}{l}\text { Cooke et al. } \\
1978\end{array}$ & USA & $\begin{array}{l}\text { Retrospective } \\
\text { Case-Control }\end{array}$ & $\begin{array}{l}\text { Forensic Psychiatric } \\
\text { Center; Elopement } \\
\text { group }(\mathrm{n}=37) ; 30 \\
\text { patients with data } \\
\text { available. Cross } \\
\text { Validation sample } \\
(\mathrm{n}=49) ; 34 \text { with data } \\
\text { available }\end{array}$ & $\begin{array}{l}\text { Random sample } \\
130 \text { non- } \\
\text { absconding } \\
\text { controls from same } \\
\text { population }\end{array}$ & Chart Review & "elope"; undefined & $\begin{array}{l}86 / 572 \text { admissions } \\
\text { over study period; } \\
15 \%\end{array}$ & $\begin{array}{l}\text { MMPI profiles (Depressive \& } \\
\text { Paranoia Scales) compared } \\
\text { between elopers and non- } \\
\text { elopers; any statistically } \\
\text { significant differences } \\
\text { weighted into prediction tool }\end{array}$ \\
\hline $\begin{array}{l}\text { Huws et al. } \\
1993\end{array}$ & U.K. & $\begin{array}{l}\text { Retrospective } \\
\text { Case-Control }\end{array}$ & $\begin{array}{l}\text { English Special } \\
\text { Hospitals over } 13- \\
\text { year period; } 66 \\
\text { incidents involving } 62 \\
\text { absconder-patients } \\
\text { during study period. } \\
\text { ( } n=32 \text { from within } \\
\text { hospital; } n=30 \text { while } \\
\text { on trial leave) }\end{array}$ & $\begin{array}{l}\text { Non-absconders } \\
\text { during same } \\
\text { period }(n=4571) \text { for } \\
\text { within hospital \& } \\
\text { discharged } \\
\text { patients for trial } \\
\text { leave absconders }\end{array}$ & Chart Review & $\begin{array}{l}\text { unauthorized absence } \\
\text { from hospital, outside } \\
\text { working party, } \\
\text { rehabilitation or } \\
\text { compassionate leave from } \\
\text { hospital, or deliberate } \\
\text { evasion of staff whilst } \\
\text { outside hospital }\end{array}$ & $\begin{array}{l}\text { "rare"; } 36 \text { over } 13 \\
\text { years out of } \\
\text { population of } 4909 ; \\
\text { rate for absconsion } \\
\text { from trial leave not } \\
\text { reported }\end{array}$ & $\begin{array}{l}\text { Predictors of absconding, } \\
\text { planning, security measures } \\
\text { of Special Hospitals, and the } \\
\text { details of the absconsion } \\
\text { outcome (offending \& danger } \\
\text { to the public) }\end{array}$ \\
\hline $\begin{array}{l}\text { Dolan et al. } \\
1994\end{array}$ & U.K. & $\begin{array}{l}\text { Retrospective } \\
\text { Case-Control }\end{array}$ & $\begin{array}{l}\text { Escaped patients } \\
\text { from regional } \\
\text { medium-secure } \\
\text { forensic unit over 7- } \\
\text { year period; } 27 \\
\text { patients; } 31 \text { escape } \\
\text { episodes }\end{array}$ & $\begin{array}{l}\text { Random sample } \\
238 \text { non-escape } \\
\text { controls from same } \\
\text { population }\end{array}$ & Chart Review & $\begin{array}{l}\text { Escapes: one or more } \\
\text { individuals who breached } \\
\text { the security of the unit and } \\
\text { subsequently attempted to } \\
\text { abscond }\end{array}$ & $\begin{array}{l}3.5 \% \text { incidence } \\
\text { among those admitted }\end{array}$ & $\begin{array}{l}\text { Frequency, characteristics of } \\
\text { incident, escapee profile, and } \\
\text { outcome of escapes; } \\
\text { determining characteristics } \\
\text { for future risk assessment }\end{array}$ \\
\hline $\begin{array}{l}\text { Gacono et al. } \\
1997\end{array}$ & USA & $\begin{array}{l}\text { Retrospective } \\
\text { Case-Control }\end{array}$ & $\begin{array}{l}\text { Maximum security } \\
\text { forensic hospital over } \\
10 \text {-year period; } 18 \\
\text { patients with escape } \\
\text { history }\end{array}$ & $\begin{array}{l}18 \text { non-escapee } \\
\text { matched controls }\end{array}$ & Chart Review & “escaped”; undefined & Not Reported & $\begin{array}{l}\text { PCL-R scores, psychotic } \\
\text { diagnosis, neuroleptic } \\
\text { medications, \& index } \\
\text { offenses compared }\end{array}$ \\
\hline
\end{tabular}




\begin{tabular}{|c|c|c|c|c|c|c|c|c|}
\hline Study & Place & Study Design & Population & $\begin{array}{l}\text { Comparison } \\
\text { Group }\end{array}$ & Intervention & Absconding Definition & Absconding Rates & Outcomes Analyzed \\
\hline $\begin{array}{l}\text { Brook et al. } \\
1999\end{array}$ & U.K. & $\begin{array}{l}\text { Retrospective } \\
\text { Case-Control }\end{array}$ & $\begin{array}{l}\text { Maximum Security } \\
\text { English Special } \\
\text { Hospital 1985-96; } \\
\text { Absconders }(n=36)\end{array}$ & $\begin{array}{l}\text { Random sample } \\
150 \text { non- } \\
\text { absconding } \\
\text { patients }\end{array}$ & Chart Review & $\begin{array}{l}\text { Unauthorized absence } \\
\text { from hospital, from an } \\
\text { authorized excursion, or } \\
\text { breach of physical security } \\
\text { of the hospital }\end{array}$ & $\begin{array}{l}36 \text { episodes across } \\
\text { study period; rates per } \\
\text { outing only available } \\
\text { for last } 4 \text { years of } \\
\text { study }(0.5,0.17,0.13 \\
\text { and } 0.17)\end{array}$ & $\begin{array}{l}\text { Absconder characteristics, } \\
\text { outcome of episode, } \\
\text { comparison between non- } \\
\text { and absconder groups } \\
\text { (demographics, clinical risk } \\
\text { factors, previous } \\
\text { absconding) }\end{array}$ \\
\hline $\begin{array}{l}\text { Moore } \\
2000\end{array}$ & U.K. & $\begin{array}{l}\text { Retrospective } \\
\text { Case-Control }\end{array}$ & $\begin{array}{l}\text { Sample of } \\
\text { absconders and } \\
\text { escapees from } 3 \\
\text { English high-security } \\
\text { hospitals between } \\
1989 \text { and } 1994 ; 43 \\
\text { incidents of } \\
\text { unauthorized absence } \\
\text { ( } 30 \text { absconsion, } 12 \\
\text { escape, and } 4 \text { failure } \\
\text { to return) by } 45 \\
\text { patients }\end{array}$ & $\begin{array}{l}\text { Absconsion: Total } \\
\text { number of outings; } \\
\text { Escape: number of } \\
\text { hospital } \\
\text { residencies per } \\
\text { year }\end{array}$ & Chart Review & $\begin{array}{l}\text { Any unauthorized absence } \\
\text { from: the hospital, } \\
\text { rehabilitation trip, an } \\
\text { outside working party, } \\
\text { leave of absence, trial } \\
\text { leave }\end{array}$ & Not Reported & $\begin{array}{l}\text { Characteristics of } \\
\text { absconding \& escape, risk } \\
\text { patterns using multi-modal } \\
\text { analysis, historical, cognitive, } \\
\text { and emotional predictive } \\
\text { factors; motivations } \\
\text { categorized }\end{array}$ \\
\hline $\begin{array}{l}\text { Moore \& } \\
\text { Hammond } \\
2000\end{array}$ & U.K. & $\begin{array}{l}\text { Retrospective } \\
\text { Case Design }\end{array}$ & $\begin{array}{l}\text { Patients of English } \\
\text { Special Hospitals } \\
\text { (Ashworth, } \\
\text { Broadmoor, \& } \\
\text { Rampton) and those } \\
\text { on trial leave 1989- } \\
\text { 1994; } 44 \text { known } \\
\text { absconders during } \\
\text { study time period }\end{array}$ & $\begin{array}{l}5,133 \text { admission } \\
\text { entries to three } \\
\text { hospitals excluding } \\
\text { absconders and } \\
\text { those discharged } \\
\text { during study time } \\
\text { period }\end{array}$ & Chart Review & See Moore, 2000 [2] & Not Reported & $\begin{array}{l}35 \text { predictor variables } \\
\text { compared between } \\
\text { absconding and non- } \\
\text { absconding groups through } \\
\text { series logistic regression } \\
\text { analyses; predictive strength } \\
\text { of variables and model } \\
\text { evaluated }\end{array}$ \\
\hline $\begin{array}{l}\text { Nichols et al. } \\
2007\end{array}$ & U.K. & $\begin{array}{l}\text { Qualitative } \\
\text { Review of } \\
\text { Absconding } \\
\text { Pack } \\
\text { Intervention; } \\
\text { and case series } \\
\text { analysis }(n=2)\end{array}$ & $\begin{array}{l}\text { Two medium secure } \\
\text { hospitals. Patients are } \\
\text { predominantly } \\
\text { mentally disordered } \\
\text { offenders }\end{array}$ & $\begin{array}{l}\text { One incident prior } \\
\text { to implementation } \\
\text { documented }\end{array}$ & $\begin{array}{l}\text { Absconsion pack } \\
\text { containing patient } \\
\text { background } \\
\text { details \& risk } \\
\text { assessment } \\
\text { factors; one } \\
\text { incident following } \\
\text { its introduction }\end{array}$ & $\begin{array}{l}\text { Vaguely "unauthorised } \\
\text { patient absence from } \\
\text { secure hospitals" including } \\
\text { escapes, failure to return } \\
\text { from leave, and } \\
\text { absconsion }\end{array}$ & "rare"; not reported & $\begin{array}{l}\text { Statistics on absconsion from } \\
\text { secure hospitals, current } \\
\text { state of social work policy, } \\
\text { recommendations; } \\
\text { development of an } \\
\text { 'absconsion pack' }\end{array}$ \\
\hline
\end{tabular}




\begin{tabular}{|c|c|c|c|c|c|c|c|c|}
\hline Study & Place & Study Design & Population & $\begin{array}{l}\text { Comparison } \\
\text { Group }\end{array}$ & Intervention & Absconding Definition & Absconding Rates & Outcomes Analyzed \\
\hline $\begin{array}{l}\text { Lyall et al. } \\
2010\end{array}$ & U.K. & $\begin{array}{l}\text { Qualitative Non- } \\
\text { Participant } \\
\text { Observational }\end{array}$ & $\begin{array}{l}\text { Data collected from } \\
\text { observation of ward } \\
\text { rounds of medium } \\
\text { secure forensic } \\
\text { unit over } 15-\text { month } \\
\text { period; Leave } \\
\text { discussed on } 96 \\
\text { occasions; risk of } \\
\text { absconding on } 12\end{array}$ & $\begin{array}{l}\text { Content of } 116 \\
\text { discussions of } 18 \\
\text { patients analyzed }\end{array}$ & $\begin{array}{l}\text { Naturalistic } \\
\text { observation of } \\
\text { weekly ward } \\
\text { rounds from two } \\
\text { clinical teams }\end{array}$ & 'running away'; undefined & $\mathrm{N} / \mathrm{A}$ & $\begin{array}{l}\text { How leave decisions are } \\
\text { reached by clinical teams: } \\
\text { factors considered, nature of } \\
\text { discussions, and two } \\
\text { emerging themes when } \\
\text { deciding on leave (risk vs } \\
\text { humanity and issues of } \\
\text { power and responsibility) }\end{array}$ \\
\hline $\begin{array}{l}\text { Stewart et al. } \\
2011\end{array}$ & U.K. & $\begin{array}{l}\text { Systematic } \\
\text { Review }\end{array}$ & $\begin{array}{l}\text { English, peer- } \\
\text { reviewed literature on } \\
\text { absconding from } \\
\text { acute mental health } \\
\text { wards and forensic } \\
\text { units, between } 1960 \\
\text { and } 2009.75 \\
\text { empirical papers } \\
\text { meeting criteria }\end{array}$ & $\begin{array}{l}\text { Open-door wards } \\
\& \text { mixed wards } \\
\text { effect on } \\
\text { absconding }\end{array}$ & $\begin{array}{l}\text { Locked- door } \\
\text { wards effect on } \\
\text { absconding }\end{array}$ & $\begin{array}{l}\text { Patient being absent from } \\
\text { the ward without official } \\
\text { permission (AWOL); } \\
\text { variations in the time } \\
\text { period a patient could be } \\
\text { absent before declared an } \\
\text { absconder (1-72 hours) }\end{array}$ & $\begin{array}{l}\text { Not Reported; Rate of } \\
\text { absconsion increased } \\
\text { as level of security } \\
\text { decreased. } \\
\text { Differences in services } \\
\text { and the characteristics } \\
\text { of patients (forensic vs } \\
\text { general psychiatric) } \\
\text { not controlled for. }\end{array}$ & $\begin{array}{l}\text { Synthesizes literature on } \\
\text { door-locking policy's effect } \\
\text { on absconsion. Increased } \\
\text { security negatively } \\
\text { associated with absconsion } \\
\text { but highly associated with } \\
\text { negative outcomes, } \\
\text { exploration of alternatives to } \\
\text { door-locking }\end{array}$ \\
\hline $\begin{array}{l}\text { Hearn et al. } \\
2012\end{array}$ & U.K. & $\begin{array}{l}\text { Review of the } \\
\text { Literature }\end{array}$ & $\begin{array}{l}\text { Papers relating to } \\
\text { absconding risk } \\
\text { assessment from } \\
\text { medium and low } \\
\text { secure mental health } \\
\text { and forensic care } \\
\text { units in the UK }\end{array}$ & $\begin{array}{l}\text { Previous risk } \\
\text { assessment } \\
\text { methodologies, } \\
\text { HCR-20, and } \\
\text { current absconding } \\
\text { interventions }\end{array}$ & $\begin{array}{l}\text { Analysis of } \\
\text { absconding risk } \\
\text { factors }\end{array}$ & $\begin{array}{l}\text { A patient who gains liberty } \\
\text { during escorted leave of } \\
\text { absence outside perimeter } \\
\text { of the unit/ hospital by } \\
\text { getting away from } \\
\text { supervision of staff. }\end{array}$ & $\begin{array}{l}\text { Not reported, noted } \\
\text { lack of consistency } \\
\text { across studies }\end{array}$ & $\begin{array}{l}\text { Prevalence, characteristics, } \\
\text { socio-environmental factors, } \\
\text { and interventions for } \\
\text { absconding, outlines the } \\
\text { LARA }\end{array}$ \\
\hline $\begin{array}{l}\text { Mezey et al. } \\
2015\end{array}$ & U.K. & $\begin{array}{l}\text { Retrospective } \\
\text { Case-Control }\end{array}$ & $\begin{array}{l}\text { Medium \& low secure } \\
\text { forensic psychiatric } \\
\text { inpatient units of two } \\
\text { NHS Trusts over } 5 \\
\text { years; } 54 \text { patients } \\
\text { responsible for } 77 \\
\text { incidents (cases); } 13 \\
\text { escape cases (12 } \\
\text { patients) }\end{array}$ & $\begin{array}{l}64 \text { absconding } \\
\text { cases ( } 42 \text { patients) }\end{array}$ & Chart Review & $\begin{array}{l}\text { Escape: breach of the } \\
\text { secure perimeter of the } \\
\text { hospital/unit; Abscond: } \\
\text { taking unauthorised liberty } \\
\text { outside perimeter, } \\
\text { breaking away from staff } \\
\text { or failure to return }\end{array}$ & $\begin{array}{l}\text { Escapes: } 0.04 \text { per } \\
1000 \text { bed days } \\
\text { Absconds: } 0.26 \text { per } \\
1000 \text { bed days; Total } \\
\text { rate of unauthorised } \\
\text { leave: } 29 \text { patients per } \\
1000 \text { admissions per } \\
\text { year }\end{array}$ & $\begin{array}{l}\text { Comparison of patient } \\
\text { characteristics, risks, } \\
\text { circumstances and outcomes } \\
\text { of cases, and motives } \\
\text { between escapee and } \\
\text { absconder groups }\end{array}$ \\
\hline $\begin{array}{l}\text { Cullen et al. } \\
2015\end{array}$ & U.K. & $\begin{array}{l}\text { Prospective } \\
\text { Cohort }\end{array}$ & $\begin{array}{l}135 \text { forensic } \\
\text { psychiatric inpatients } \\
\text { (medium \& low secure } \\
\text { wards) over 2-year } \\
\text { follow-up; } 27 \text { patients } \\
\text { responsible for } 56 \\
\text { absconsions during } \\
\text { study period }\end{array}$ & $\begin{array}{l}108 \text { non- } \\
\text { absconder patients }\end{array}$ & $\begin{array}{l}\text { Incidents of } \\
\text { Absconsion }\end{array}$ & $\begin{array}{l}\text { Absent from hospital } \\
\text { without permission (i.e., } \\
\text { failure to return from } \\
\text { leave, escape, and } \\
\text { absconding whilst on } \\
\text { escorted leave) }\end{array}$ & $\begin{array}{l}20 \% \text { of population } \\
\text { studied }\end{array}$ & $\begin{array}{l}\text { Demographic, clinical, } \\
\text { treatment-related, and } \\
\text { offending/behavioural factors } \\
\text { from EMRs \& census of } \\
\text { treatment teams used for } \\
\text { predictive risk scale (low } \\
\text { PPV) }\end{array}$ \\
\hline
\end{tabular}




\begin{tabular}{|c|c|c|c|c|c|c|c|c|}
\hline Study & Place & Study Design & Population & $\begin{array}{l}\text { Comparison } \\
\text { Group }\end{array}$ & Intervention & Absconding Definition & Absconding Rates & Outcomes Analyzed \\
\hline $\begin{array}{l}\text { Wilkie et al. } \\
2014\end{array}$ & CAN & $\begin{array}{l}\text { Retrospective } \\
\text { Case-Control }\end{array}$ & $\begin{array}{l}\text { Forensic patients } \\
\text { within a large } \\
\text { psychiatric hospital in } \\
\text { Toronto (medium \& } \\
\text { minimum security); } 57 \\
\text { patients responsible } \\
\text { for at least one } \\
\text { incident ( } n=102 \text { ) from } \\
\text { hospital within } \\
\text { previous } 24 \text {-months }\end{array}$ & $\begin{array}{l}57 \text { matched non- } \\
\text { absconder control } \\
\text { group with no } \\
\text { previous history of } \\
\text { absconsion }\end{array}$ & Chart Review & $\begin{array}{l}\text { Any unauthorized absence } \\
\text { from hospital: breaching } \\
\text { the security of inpatient } \\
\text { unit, accessing hospital } \\
\text { grounds/community } \\
\text { without permission, or } \\
\text { absent for longer than } \\
\text { permitted }\end{array}$ & $14.4 \%$ over two years & $\begin{array}{l}\text { Characteristics of } \\
\text { absconders; outcomes of } \\
\text { event and motives; } \\
\text { significant differences } \\
\text { between of patients with and } \\
\text { without absconding incidents } \\
\text { used to identify factors } \\
\text { predictive of absconding } \\
\text { (HCR-20, PCL-R) }\end{array}$ \\
\hline $\begin{array}{l}\text { Simpson et al. } \\
2015\end{array}$ & CAN & $\begin{array}{l}\text { A-B prospective } \\
\text { design for Leave } \\
\text { Application } \\
\text { Form }\end{array}$ & $\begin{array}{l}\text { Forensic program at a } \\
\text { large urban } \\
\text { psychiatric hospital in } \\
\text { Toronto over } 42- \\
\text { month study window; } \\
86 \text { patients } \\
\text { responsible for } 188 \\
\text { incidents of } \\
\text { absconding }\end{array}$ & $\begin{array}{l}\text { Compared and } \\
\text { matched (on age, } \\
\text { sex, and security } \\
\text { level within the } \\
\text { hospital) to non- } \\
\text { absconder controls }\end{array}$ & $\begin{array}{l}\text { Leave Application } \\
\text { Form integrating } \\
\text { HCR-20 risk } \\
\text { indicators, nature } \\
\text { \& purpose of } \\
\text { leave, risks \& } \\
\text { benefits of } \\
\text { granting leave, } \\
\text { and rehabilitative } \\
\text { goals }\end{array}$ & See Wilke et al. 2014 & $\begin{array}{l}\text { Absconding rate } \\
\text { decreased } 33 \% \\
(p<.05) \text { Prior } \\
\text { implementation: } \\
17.8 \% \text { During } \\
\text { implementation: } \\
13.8 \% \text { Post- } \\
\text { implementation: } \\
12.0 \%\end{array}$ & $\begin{array}{l}\text { Rate, characteristics, } \\
\text { motivations of absconding } \\
\text { events prior to and following } \\
\text { new policy; comparison } \\
\text { between absconders and } \\
\text { non-absconders during study } \\
\text { period (HCR-20, length of } \\
\text { stay, substance use) }\end{array}$ \\
\hline $\begin{array}{l}\text { Scott et al. } \\
2017\end{array}$ & AUS & $\begin{array}{l}\text { Retrospective } \\
\text { descriptive audit }\end{array}$ & $\begin{array}{l}\text { High Security } \\
\text { Inpatient Services } \\
\text { (HSIS), Brisbane over } \\
12-\text { year study period; } \\
\text { forensic and general } \\
\text { psychiatric units; } 27 \\
\text { AWOP incidents } \\
\text { between 2003-2015 } \\
\text { (14 patients) }\end{array}$ & $\begin{array}{l}\text { Total Episodes of } \\
\text { Day Leave }\end{array}$ & Chart Review & $\begin{array}{l}\text { Critical incidents during } \\
\text { leave: breaches of the } \\
\text { conditions of leave (fleeing } \\
\text { staff), failure to return from } \\
\text { leave by the designated } \\
\text { time or AWOP; criminal } \\
\text { offending, harming } \\
\text { others/self-harming on } \\
\text { leave }\end{array}$ & $\begin{array}{l}1 \text { in } 1710 \text { incidence of } \\
\text { AWOPs relative to } \\
\text { total day leave } \\
\text { episodes across } 12 \\
\text { years }\end{array}$ & $\begin{array}{l}\text { Characteristics of critical } \\
\text { incidents, outcomes of } \\
\text { (harm, re-offense, returns), } \\
\text { predictors (history of } \\
\text { absconding) }\end{array}$ \\
\hline
\end{tabular}


Amongst studies that provided a definition of absconding, there were variations in time-periods a patient could be absent before being deemed an absconder $[1,3,4,6,7,13]$. In addition, most studies classified both failures to return from leave and escape as absconsion [6,10]. One study differentiated between escape and absconsion [7] and only one clearly differentiated between absconding, failure to return from leave, escape, and attempts $[1,12,13]$. Three studies did not include definitions at all [18,23,27].

\section{Static Risk Factors}

History of previous absconsion or attempts was found to be significantly associated with future absconding incidents in many studies $[2,4-9,14]$. Those who abscond are likely to be young, Caucasian, male, and diagnosed with a psychotic disorder, compared to non-absconders [1,5,13,18]. A history of alcoholism, unemployment, and being an older sibling was characteristic of some absconders [10]. Some studies looked at scores on commonly used violence risk assessment tools. Higher risk scores on the HCR-20 were noted in three studies as being a good predictor of absconding behaviour [4,9,11]. Higher PCL-R scores of absconders and escapes were also associated with a higher risk of absconding $[4,11,27]$.

\section{Dynamic Risk Factors}

Absconding was also found to be significantly associated with dynamic factors such as patients' acute mental state or recent stressful events such as death/loss or transitions in care (usually from lower to higher security) $[4,11,14,25]$. Furthermore, in the year prior to absconding, absconders were more likely to be involved in property damage, verbal aggression, self-harm, substance abuse and to be non-compliant with treatment [3$5,9]$. Absconders were more likely to have a comorbid substance use disorder and problematic personality traits/disorder than personality disorder alone [9,11].

\section{Motivations to Abscond}

Only four studies to date have included explicit analysis of specific motivational factors $[4,6,9,11]$. Two commented on particular subgroups of absconders: opportunity makers and opportunity takers $[2,4]$. Opportunity takers make up the majority of absconders, meaning those who make use of circumstances or chance events where impulsivity, fear of transfer, revoking of parole, amount of money in possession, and difficulties in accepting detention are associated with increased risk $[2,4]$. Opportunity makers, by contrast, engineer situations in which they can abscond, and absconsion was often goaloriented and planned, especially with those from higher security wards [2,4-6]. Researchers identified four distinct motivations of absconding behavior: goaldirected, frustration/boredom, symptomatic/disorganized, and accidental $[4,9,11]$. Frustration/boredom and goaldirected behaviours account for the vast majority of incidents $[4,11]$. These patients often exhibited higher HCR-20 scores, difficult behaviors, absconding ideation and voicing of discontent to staff, and upcoming or recently unfavourable Review Board hearings in the weeks prior to absconding $[4,9,11]$. When individuals returned, it was at their leisure, they minimized the situation, externalized blame, or defended behavior [4]. Goal-directed individuals are those with a desire to abscond in order to complete a specific goal which they were likely to have voiced to staff $[4,9]$. Symptomatic/disorganized absconders appeared to act in response to auditory hallucinations or delusional beliefs $[4,9,11]$. Active symptoms of illness, notable instability, medication changes, missed medication and stating of psychotic beliefs with absconding ideation preceded incidents [4,9]. Accidental absconders were those who lost track of time or met situations beyond their control resulting in a report of absconsion [4,9,11].

\section{Characteristics of Absconding Incidents}

Incidents of absconding from secure hospitals were found to be rare and acts of violence during absconsion were infrequent $[1-4,6,8,11,12]$. Incidents occurring in lowsecurity units appeared to be higher compared to medium or maximum-security units $[3,5,7,13]$. Most absconding incidents occurred from individual or community trips outside the hospital $[3-5,8,13]$. The number 
of escorts had little impact on reducing the risk of absconding $[2,5,14]$. In most cases, only one patient absconded, but there are several reports of patients absconding together [2-5,7].

\section{Timing of Absconding}

Some studies observed that most incidents occurred during warm weather from May to September and in holiday months such as December when patients wished to be close to loved ones $[4,10]$. One study noted absconsion took place primarily during the afternoon/evening, weekends or times with lower staff level [6]. Two studies indicated that absconsions tended to occur in clusters suggesting a "copycat" or "contagion" effect during times of ward stress $[5,6]$. There is disagreement over whether length of stay is related to absconsion risk. Three studies confirmed significant time lapses between the date of admission and first absconsion episode $[4,9,28]$. One study noted that the longer a patient has been known to staff and not absconded; the less likely staff may be to expect absconsion, increasing the risk [28]. This is inconsistent with previous research, which hypothesized no relationship, or that risk of absconsion is highest earlier in inpatient stay when patients are unsettled or resentful $[7,10,28]$. Because of conflicting data about timings of absconsion, focusing instead on motivations behind observed trends may be more useful in assessing risk than the static factor of length of stay $[4,6,7,9,10,14,28]$.

\section{Outcomes of Absconsion}

Forensic absconsion is rare, with locked doors and high secure units correlated to the lowest rates, but with overall rates increasing [1-8]. Studies focused on the duration of absconding events and circumstances of the return, (see Table 1) and in most cases the duration was short, the majority of patients were returned within 24 hours, and all absconders were eventually found $[1-6,8,11,12]$. A recent study noted the median absconding duration of only 4 hours [11], and one noted most patients were caught within minutes by hospital staff [5]. Between suburban and urban hospital settings, it may be easier for absconders to evade detection and gain access to the wider community in a metropolitan city $[4,11,26]$. Police were involved in the patients' recapture usually without incident, and in some cases, the patients returned voluntarily, although this was less likely in escapees [5,7]. The ultimate level of public endangerment posed by those who absconded is low, with few patients reoffending during absence [24]. An Ontario forensic institution found that despite higher HRC-20 scores and substance-use disorders among the 57 patients responsible for 102 absconsions over 2 years, only one incident of minor violence and very few other illegal behaviours occurred [4]. Three English maximum-security hospitals had very low rates of absconding from thousands of rehabilitation outings over a five-year period, all with minimal risk to the public [2]. Huws et al., reported 11 cases of offending from 36 AWOPs over 13 years, and with only two serious offences (rape and manslaughter) [3]. Several studies noted negative outcomes for absconders: selfharm during leave, elevated risk of suicide upon return, and substance abuse during leave $[1-4,8,15]$. Beyond public safety risks, re-offense, and patient harm, other outcomes included slowed patient rehabilitation, the reputational risk to the hospital, affects on the legal status of the patient, and perpetuation of stigma towards patients [1-11,18]. 


\section{Table 2: CASP Checklists}

A. Completed CASP qualitative risk of bias checklist tool

\begin{tabular}{|c|c|c|c|c|c|c|c|c|c|c|}
\hline & $\begin{array}{l}\text { Clearly stated } \\
\text { research } \\
\text { aims? }\end{array}$ & $\begin{array}{l}\text { Is a qualitative } \\
\text { methodology } \\
\text { appropriate? }\end{array}$ & $\begin{array}{l}\text { Was the } \\
\text { research } \\
\text { design } \\
\text { appropriate to } \\
\text { address the } \\
\text { research } \\
\text { aims? }\end{array}$ & $\begin{array}{l}\text { Was the } \\
\text { recruitment } \\
\text { strategy } \\
\text { appropriate to } \\
\text { the research } \\
\text { aims? }\end{array}$ & $\begin{array}{l}\text { Was the data } \\
\text { collected in a } \\
\text { way that } \\
\text { addressed the } \\
\text { research } \\
\text { issue? }\end{array}$ & $\begin{array}{l}\text { Relationship } \\
\text { between } \\
\text { researcher } \\
\text { and } \\
\text { participants } \\
\text { adequately } \\
\text { considered? }\end{array}$ & $\begin{array}{l}\text { Have ethical } \\
\text { issues been } \\
\text { considered? }\end{array}$ & $\begin{array}{l}\text { Was data } \\
\text { analysis } \\
\text { sufficiently } \\
\text { rigorous? }\end{array}$ & $\begin{array}{l}\text { Clear } \\
\text { statement of } \\
\text { findings? }\end{array}$ & $\begin{array}{l}\text { How valuable } \\
\text { is the } \\
\text { research? }\end{array}$ \\
\hline $\begin{array}{l}\text { Lyall et al. } \\
2010\end{array}$ & $\mathrm{Y}$ & $\mathrm{Y}$ & $Y$ & Can't Tell & $\mathrm{Y}$ & Can't Tell & $\mathrm{Y}$ & $\mathrm{Y}$ & $Y$ & Moderate \\
\hline Nichols 2007 & Y & $Y$ & $Y$ & Can't Tell & Y & Y & Y & $\mathrm{N}$ & $Y$ & Very \\
\hline
\end{tabular}

B. Completed CASP case-control risk of bias checklist tool

\begin{tabular}{|c|c|c|c|c|c|c|c|c|c|c|}
\hline & $\begin{array}{l}\text { Did the study } \\
\text { address a } \\
\text { clearly } \\
\text { focused } \\
\text { issue? }\end{array}$ & $\begin{array}{l}\text { Appropriate } \\
\text { method to } \\
\text { answer their } \\
\text { question? }\end{array}$ & $\begin{array}{l}\text { Were cases } \\
\text { recruited in } \\
\text { an } \\
\text { acceptable } \\
\text { way? }\end{array}$ & $\begin{array}{l}\text { Were } \\
\text { controls } \\
\text { selected in } \\
\text { an } \\
\text { acceptable } \\
\text { way? }\end{array}$ & $\begin{array}{l}\text { Was } \\
\text { exposure } \\
\text { accurately } \\
\text { measured to } \\
\text { minimise } \\
\text { bias? }\end{array}$ & $\begin{array}{l}\text { Were the } \\
\text { groups } \\
\text { treated } \\
\text { equally? }\end{array}$ & $\begin{array}{l}\text { Have authors } \\
\text { taken } \\
\text { account of } \\
\text { potential } \\
\text { confounders? }\end{array}$ & $\begin{array}{l}\text { Do you } \\
\text { believe the } \\
\text { results? }\end{array}$ & $\begin{array}{l}\text { Can the } \\
\text { results be } \\
\text { applied to the } \\
\text { local } \\
\text { population? }\end{array}$ & $\begin{array}{l}\text { Do results of } \\
\text { study fit with } \\
\text { other } \\
\text { available } \\
\text { evidence? }\end{array}$ \\
\hline $\begin{array}{l}\text { Brook et al. } \\
1999\end{array}$ & $\mathrm{Y}$ & $\mathrm{Y}$ & $\mathrm{Y}$ & Y & $\mathrm{Y}$ & $\mathrm{Y}$ & $\mathrm{Y}$ & Y & $\mathrm{Y}$ & $\mathrm{Y}$ \\
\hline $\begin{array}{l}\text { Cooke et al. } \\
1978\end{array}$ & $\mathrm{Y}$ & $\mathrm{Y}$ & Can't Tell & $Y$ & $\mathrm{Y}$ & $\mathrm{Y}$ & Can't Tell & Y & $\mathrm{Y}$ & $\mathrm{Y}$ \\
\hline $\begin{array}{l}\text { Dolan et al. } \\
1994\end{array}$ & $\mathrm{Y}$ & $\mathrm{Y}$ & $\mathrm{Y}$ & Y & $\mathrm{Y}$ & $\mathrm{Y}$ & $\mathrm{Y}$ & Y & Y & $\mathrm{Y}$ \\
\hline $\begin{array}{l}\text { Gacono et al. } \\
1997\end{array}$ & $\mathrm{Y}$ & Y & Can't Tell & $\mathrm{Y}$ & $\mathrm{Y}$ & $\mathrm{Y}$ & $\mathrm{Y}$ & Y & $\mathrm{Y}$ & $\mathrm{Y}$ \\
\hline $\begin{array}{l}\text { Huws et al. } \\
1993\end{array}$ & $\mathrm{Y}$ & $\mathrm{Y}$ & $\mathrm{Y}$ & $Y$ & Can't Tell & $\mathrm{Y}$ & $Y$ & Y & $\mathrm{Y}$ & $\mathrm{Y}$ \\
\hline $\begin{array}{l}\text { Martin et al. } \\
2018\end{array}$ & $\mathrm{Y}$ & $\mathrm{Y}$ & $\mathrm{Y}$ & Y & $\mathrm{Y}$ & Y & $\mathrm{Y}$ & Y & Y & $\mathrm{Y}$ \\
\hline $\begin{array}{l}\text { Mezey et al. } \\
2015\end{array}$ & $\mathrm{Y}$ & $\mathrm{Y}$ & $\mathrm{Y}$ & $\mathrm{N}$ & $\mathrm{Y}$ & $\mathrm{Y}$ & $\mathrm{Y}$ & $\mathrm{Y}$ & Can't Tell & $\mathrm{Y}$ \\
\hline $\begin{array}{l}\text { Moore \& } \\
\text { Hammond } \\
2000\end{array}$ & $\mathrm{Y}$ & $\mathrm{Y}$ & $\mathrm{Y}$ & $Y$ & $\mathrm{Y}$ & $\mathrm{Y}$ & $\mathrm{Y}$ & Y & $\mathrm{Y}$ & $\mathrm{Y}$ \\
\hline $\begin{array}{l}\text { Morrow et al. } \\
1969\end{array}$ & $\mathrm{Y}$ & $\mathrm{Y}$ & Can't Tell & Y & $\mathrm{Y}$ & $\mathrm{Y}$ & $\mathrm{Y}$ & Y & $\mathrm{Y}$ & $\mathrm{Y}$ \\
\hline $\begin{array}{l}\text { Scott et al. } \\
2017\end{array}$ & $\mathrm{Y}$ & Y & $\mathrm{Y}$ & $\mathrm{Y}$ & Y & $\mathrm{Y}$ & $\mathrm{Y}$ & $\mathrm{Y}$ & $\mathrm{Y}$ & $\mathrm{Y}$ \\
\hline $\begin{array}{l}\text { Wilkie et al. } \\
2014\end{array}$ & $\mathrm{Y}$ & $\mathrm{Y}$ & $\mathrm{Y}$ & $Y$ & $Y$ & $\mathrm{Y}$ & $Y$ & Y & $\mathrm{Y}$ & $\mathrm{Y}$ \\
\hline
\end{tabular}




\section{Completed CASP cohort risk of bias checklist too}

\begin{tabular}{|c|c|c|c|c|c|c|c|c|c|c|c|}
\hline & $\begin{array}{l}\text { Did the study } \\
\text { address a } \\
\text { clear issue? }\end{array}$ & $\begin{array}{l}\text { Cohort } \\
\text { recruited in } \\
\text { acceptable } \\
\text { way? }\end{array}$ & $\begin{array}{l}\text { Exposure } \\
\text { accurately } \\
\text { measured } \\
\text { minimising } \\
\text { bias? }\end{array}$ & $\begin{array}{l}\text { Outcome } \\
\text { accurately } \\
\text { measured } \\
\text { minimising } \\
\text { bias? }\end{array}$ & $\begin{array}{l}\text { Have the } \\
\text { authors } \\
\text { identified all } \\
\text { important } \\
\text { confounding } \\
\text { factors? }\end{array}$ & $\begin{array}{l}\text { Have they } \\
\text { taken } \\
\text { account of } \\
\text { confounders } \\
\text { in the design } \\
\text { /analysis? }\end{array}$ & $\begin{array}{l}\text { Was the } \\
\text { follow up } \\
\text { complete and } \\
\text { long enough? }\end{array}$ & $\begin{array}{l}\text { Do you } \\
\text { believe } \\
\text { results? }\end{array}$ & $\begin{array}{l}\text { Can the } \\
\text { results be } \\
\text { applied to the } \\
\text { local } \\
\text { population? }\end{array}$ & $\begin{array}{l}\text { Do the } \\
\text { results of this } \\
\text { study fit with } \\
\text { available } \\
\text { evidence? }\end{array}$ & $\begin{array}{l}\text { Are there } \\
\text { implicat-ions } \\
\text { of this study } \\
\text { for practice? }\end{array}$ \\
\hline $\begin{array}{l}\text { Cullen et al. } \\
2015\end{array}$ & $\mathrm{Y}$ & Y & Y & $Y$ & $\mathrm{Y}$ & Y & $\mathrm{Y}$ & Can't Tell & Can't Tell & Y & $Y$ \\
\hline $\begin{array}{l}\text { Simpson et } \\
\text { al. } 2015\end{array}$ & $\mathrm{Y}$ & Y & Y & Y & Y & Y & $Y$ & Y & $\mathrm{Y}$ & $\mathrm{Y}$ & $\mathrm{Y}$ \\
\hline
\end{tabular}

D. Completed CASP systematic review risk of bias checklist tool

\begin{tabular}{|c|c|c|c|c|c|c|c|c|}
\hline & $\begin{array}{l}\text { Did the } \\
\text { review } \\
\text { address a } \\
\text { clearly } \\
\text { focused } \\
\text { question? }\end{array}$ & $\begin{array}{l}\text { Did the } \\
\text { authors look } \\
\text { for the right } \\
\text { type of } \\
\text { papers? }\end{array}$ & $\begin{array}{l}\text { Do you think } \\
\text { all the } \\
\text { important, } \\
\text { relevant } \\
\text { studies were } \\
\text { included? }\end{array}$ & $\begin{array}{l}\text { Did the } \\
\text { review's } \\
\text { authors do } \\
\text { enough to } \\
\text { assess } \\
\text { quality of the } \\
\text { included } \\
\text { studies? }\end{array}$ & $\begin{array}{l}\text { If the results } \\
\text { of the review } \\
\text { have been } \\
\text { combined, } \\
\text { was it } \\
\text { reasonable to } \\
\text { do so? }\end{array}$ & $\begin{array}{l}\text { Can the } \\
\text { results be } \\
\text { applied to the } \\
\text { local } \\
\text { population? }\end{array}$ & $\begin{array}{l}\text { Were all } \\
\text { important } \\
\text { outcomes } \\
\text { considered? }\end{array}$ & $\begin{array}{l}\text { Are the } \\
\text { benefits } \\
\text { worth the } \\
\text { harms and } \\
\text { costs? }\end{array}$ \\
\hline Cochrane & & Y & Can't Tell & Y & $N$ & Can't Tell & Y & $Y$ \\
\hline $\begin{array}{l}\text { Hearn et al. } \\
2012\end{array}$ & Y & Y & Can't Tell & Y & Y & Can't Tell & Y & $\mathrm{Y}$ \\
\hline $\begin{array}{l}\text { Stewart et al. } \\
2010\end{array}$ & Y & Y & Can't Tell & Y & Y & $Y$ & Y & $Y$ \\
\hline
\end{tabular}




\section{Discussion}

Within this review, the use of an a priori protocol, defined research question, objectives, and scope reduces bias in selection [29]. The major limitation in this review was the scarcity of data on absconsion within the forensic population, prompting date range adjustment to include as many relevant studies as possible. Inconsistent definitions of absconsion made it difficult to draw comparisons between studies, as well as inconsistent reporting of rates, comparison groups, and settings (see Table 1). CASP is seen generally seen as an appropriate tool for qualitative risk of bias assessment, however, it appears to be inferior to others in terms of sensitivity $[25,30]$. Studies were all found to be of qualitative value to include in a review of the literature, individual article limitations were examined, and all were found to be of low risk of bias as per CASP guidelines (see Table 4 A-D).

Despite its rarity, cases where patients were gone for extended periods, used hospital and police resources, did commit offenses, or had negative outcomes themselves reaffirms palpable risks and consequences of absconsion [1-6,8,12,19]. These outcomes derail rehabilitative goals and demonstrate the negative consequences for absconders as well [1$4,8,9,11,14,15]$. The absence of an overwhelming number of adverse incidents may help relieve the public's beliefs about safety concerns $[2,8,9,18]$. To reduce negative outcomes of absconsion an "absconding pack" given to police may improve response time and streamline the recovery process $[12,19]$. While primarily proof of concept, this study encourages increased standardization in forensic patient data collection [19].

The deficiency in volume and quality of literature on the topic of absconsion from forensic institutions may reflect the rarity of such incidences, resulting in smaller sample sizes and difficulties in producing comparisons. The small sample sizes or discrepancy between sizes of control and absconding groups in individual studies affects the significance of results measured in case-control and cohort studies and the ability to assess risk factors [5,28]. Attempts were made to minimize confounding factors and bias in some studies by having a control group, matched comparison group of non-absconders, or other comparison group, though appropriate matching criteria were difficult to discern and inconsistent across studies $[2,3,5-8,10,11,18,27,28]$. The past 10 years have seen an increase in forensic absconsion literature, possibly attributable to negative media responses to increasing rates or recent high profile absconsions prompting interest in better risk management and increased pressure for understanding of outcome risks and motivations as mentioned in some studies [2-4].

Most research conducted was retrospective in nature. Due to incomplete EMRs and biased clinician recall, many retrospective studies were operating with incomplete data and particularly limited in exploring dynamic risks $[2,3,5,7]$. Selection bias was evident when outcomes were not available for several absconders, or for attempts, especially considering history of absconding being a stable predictor $[2,4$ $9,14,18]$. Limitations of retrospective analysis based on EMRs is further compounded by the fact that there exists no evidence of systematic documentation for absconding episodes across forensic institutions over time. While retrospective studies attempted to discern absconder profiles, characteristics, and motivations many noted these were based off incomplete records $[2,3,5-8,10,11,18$, $27,28]$. Refinement of record-keeping of incidents may assist in the better extrapolation of risk factors [5,19]. A standard debriefing protocol for patients who have been returned could further inform motivations and strengthen therapeutic relationships $[4,5,9]$.

Given that risks and factors have been established from retrospective studies, more prospective studies should be undertaken. These should incorporate a standardized definition of absconding from forensic institutions and conduct in-depth analysis of motives and characteristics on 
larger forensic sample sizes to replicate the significance and clinical utility of risk factors previously identified in retrospective literature.

Additionally, literature reviews pooled both forensic and general psychiatric populations in their analyses $[1,12,13]$. It is imperative to study forensic populations separately; there are differences between forensic patients and general psychiatric patients and the systems through which they receive rehabilitative treatment, that impacts how we analyze absconsion from these settings and development of appropriate risk tools [16,23,29]. General psychiatric patients may be admitted voluntarily or involuntarily depending on clinical presentation, while criminal history and serious mental illness are inherent for admittance to a forensic psychiatric facility $[12,23-25,27]$. The forensic patient also experiences the unique stresses associated with the forensic system, such as decreased autonomy, increased length of stay, Review Board hearings, revocation of liberty, and heightened security and stigma due to their criminal offenses [11,2224,27]. Ultimately these clear differences between the two settings that warrant separate investigations into factors associated with absconsion from these two distinct populations, and a review of forensic-specific literature is warranted $[1,12,13]$.

One of the biggest gaps is in risk assessment. At present only one qualitative study has contributed to the understanding of clinician decision making in granting forensic leave however the researcher's own influence needed to be reviewed for observation bias and reporting bias being the sole observer [23]. These leave decisions tend to be unstructured, with absconding risk and current mental state rarely referenced explicitly, and time constraints predisposing conversations to brevity [23]. Despite attempts, overall, there still exists no "thorough, well designed, rigorously carried-out trials of interventions to reduce absconding" valid for forensic populations $[9,12,15]$. Two studies that were analyzed explored tools incorporating validated and widely used violence risk and psychopathy assessment scales such as the HCR-20 and PCL-R that showed utility in predicting absconsion, so further analysis of these scales' absconsion predictivity would be valuable $[4,9,12]$. The LARA is based on a review of violent risk assessment and absconsion literature, but the tool has not yet been tested for validity/reliability and is not specific to forensic settings [12]. The LARA could be refined for forensic use, although it would need to be tested prospectively [12]. Prospective analysis of an empiricallyderived Leave Application Form to assist clinical teams in leave decisions showed a $33 \%$ decrease in absconding following implementation in one population [4,9]. Future cross-referencing of this form's validity in different settings would aid in confirming its reliability and shows promise for evolving into a standardized forensic tool [9]. In addition to EMR review, interviewing patients about past absconsions to further discern motivational risks to be incorporated into a tool would be valuable $[9,12]$. Ultimately literature is starting to emerge but any proposed risk assessment tools are in very early stages.

Statistical risk prediction of absconsion is inherently problematic due to the low volume of forensic absconding events, and risk assessment based on static and demographic factors may not be appropriate $[12,28]$. While compared in nearly all retrospective chart reviews, demographic factors may be time and context-specific, or the offender patient population at one institution may be skewed depending on the type of surrounding community from which patients originate $[12,28]$. History of absconsion, recent PCL$R$, and HCR-20 remaining steadily predictive across studies may be related to consistent motivations $[1,4,6,9,11,27]$. Clinical interventions may affect observed findings for factors such as definite psychopathy and record of physical violence being negatively associated with absconsion, as clinical teams may impose additional restrictions on those who have high-risk diagnoses or violent behaviour $[13,14]$. These patients may thus present as lower risk since they have fewer opportunities to abscond, rather than these 
characteristics actually representing lowrisk.

Retrospective studies have thoroughly established static factors, and several acknowledge the potential weight of motivational factors, yet very little has been done to actually evaluate motivational factors as this data is difficult to obtain retrospectively $[4,11,12,14,25]$. Recent stressful life events and clinical events should be carefully monitored in patients in the context of their relationship to potential motivators since they may increase frustration, be indicative of boredom, precede goal-oriented behaviour, or aggravate symptoms of mental illness prompting accidental or symptomatic absconsion $\quad[3-5,9,11,12,14, \quad 25,27]$. Clinicians acknowledge the time spent without leave on a ward is frustrating and contributes to a negative rehabilitative environment, boredom, and despair for patients facing long hospitalizations alongside the revocation of their autonomy compared to other psychiatric settings $[1,4,6,7,9,11]$. Substance use is unsurprisingly a predominant subtype of goal-directed motivation [4,7]. Future prospective analysis should also consider incorporating patient and staff interviews alongside medical record review following absconsion to better discern patient motives.

Behaviours that are strong predictors for absconsion in forensic settings could be potentially targeted with appropriate preventative interventions [4,7]. For instance, if substance abuse is both a motivator and risk factor for absconsion, an inpatient program for patients targeting substance use disorders could prove effective $[4,7]$. Although the most straight forward method of reducing absconding would seem to be to increase hospital wide

\section{References}

1. Muir-Cochrane E, Mosel KA. Absconding: A review of the literature 1996-2008. Int J Ment Health Nurs 2008;17(5):370-8

2. Moore E. A descriptive analysis of incidents of absconding and escape from the English highsecurity hospitals, 1989-94. J Forensic Psychiatr 2000;11:344-58 security, locking ward doors and reducing leave, such measures do not stop absconding altogether and need to be balanced against potential negative consequences such as a volatile ward environment, depression associated with lack of freedom, and negative acute mental states $[4,11,13,14,25]$.

Finally, several studies suggested ensuring adequate staffing levels and relational security, increasing positive relationships with the clinical team, and improving the education of staff themselves on risks and precipitators to absconsion in order to better detect their presence, would aid in creating a cohesive, transparent, rehabilitative environment for patients $[4,6,9,23]$.

\section{Conclusion}

Ultimately, there is a deficit in forensicsetting literature and inconsistency in many areas of interest on absconsion. While a rare event of ultimately low risk to the public, there is a need to develop a consistent definition of absconsion and use standardized reporting for incidents and outcomes across forensic settings. Prospective studies with patient interviews centered on absconder motivations and acute mental state should be undertaken so as to rely less on static risk factors and retrospective data. Development of a validated forensic absconsion risk assessment tool based on evidence, and preventative measures targeting motivations will aid in reducing risk.

Conflict of Interest: none

3. Huws R, Shubsachs A. A study of absconding by special hospital patients: 1976 to 1988. J Forensic Psychiatr 1993;4(1):45-58

4. Wilkie T, Penney SR, Fernane S, Simpson AIF. Characteristics and motivations of absconders from forensic mental health services: A casecontrol study. BMC Psychiatry 2014;14(1): 91 
5. Brook R, Dolan M, Coorey P. Absconding of patients detained in an English Special Hospital. J Forensic Psychiatr 1999;10(1):46-58

6. Dolan M, Snowden P. Escapes from a medium secure unit. J Forensic Psychiatr 1994;5(2): 27586

7. Mezey G, Durkin C, Dodge L, White S. Never ever? characteristics, outcomes and motivations of patients who abscond or escape: A 5-year review of escapes and absconds from two medium and low secure forensic units. Crim Behav Ment Health 2015;25(5):440-50

8. Scott R, Meehan T. Critical incidents during leave from an Australian security hospital - A 12year audit. Psychiatr Psychol Law 2017; 24(1):47-60

9. Simpson AIF, Penney SR, Fernane S, Wilkie T. The impact of structured decision making on absconding by forensic psychiatric patients: Results from an A-B design study. BMC Psychiatry 2015;15:103

10. Morrow WR. Escapes of psychiatric offenders. $J$ Crim Law Criminol 1969;60:464-71

11. Martin K, McGeown M, Whitehouse M, Stanyon W. Who's going to leave? an examination of absconding events by forensic inpatients in a psychiatric hospital. $J$ Forensic Psychiatr Psychol 2018;29(5):810-23

12. Hearn D, Ndegwa D, Norman P, Hammond N, Chaplin E. Developing the leave/abscond risk assessment (LARA) from the absconding literature: an aide to risk management in secure services. Adv Ment Health Intellect Disabil 2012;6(6):280-90

13. Stewart D, Bowers L. Absconding and locking ward doors: Evidence from the literature. J Psychiatr Ment Health Nurs 2011;18(1):89-93

14. Cullen AE, Jewell A, Tully J, Coghlan S, Dean K, Fahy T. A prospective cohort study of absconsion incidents in forensic psychiatric settings: Can we identify those at high-risk? PloS One 2015;10(9):e0138819

15. Bowers L, Jarrett M, Clark N. Absconding: a literature review. J Psychiatr Ment Health Nurs 1998;5(5):343-53

16. Crammer JL. The special characteristics of suicide in hospital in-patients. Br J Psychiatry 1984;145(5):460-3

17. Wilson CM, Crocker AG, Nicholls TL, Charette $\mathrm{Y}$, Seto MC. The use of risk and need factors in forensic mental health decision-making and the role of gender and index offense severity. Behav Sci Law 2015;33(1):19-38
18. Cooke G, Thorwarth C. Prediction of elopement of mentally ill offenders using the MMPI. Correctional Psychologist 1978;5(2):151-57

19. Nichols T. Absconding from secure units: a review and description of an 'absconding pack' implications for wider use. J Ment Health Train Educ Pract 2007;2(2):22-7

20. Mezey GC, Kavuma M, Turton P, Demetriou A, Wright C. Perceptions, experiences and meanings of recovery in forensic psychiatric patients. J Forensic Psychiatr Psychol 2010;21(5):683-96

21. Simpson Al, Penney SR. The recovery paradigm in forensic mental health services. Crim Behav Ment Health 2011;21(5):299-306

22. Bettridge S., Barbaree H., Psych C. The forensic mental health system in Ontario. CAMH. 2008. (accessed on October 2, 2019)

23. Lyall $M$, Bartlett $A$. Decision making in medium security: Can he have leave? J Forensic Psychiatr Psychol 2010;21(6):887-901

24. Sharma A, Dunn WR, Kennedy HG. The virtual institution: cross-sectional length of stay in general adult and forensic psychiatry beds. Int $J$ Ment Health Syst 2015;9(1):25

25. Critical Appraisal Skills Programme. CASP Appraisal Checklists. (accessed on October 2, 2019)

26. Moher D, Liberati A, Tetzlaff J, Altman DG, The PRISMA Group. Preferred Reporting Items for Systematic Reviews and Meta-Analyses: The PRISMA Statement. PLoS Med 2009;6(7): e1000097

27. Gacono CB, Meloy JR, Speth E, Roske A. Above the law: Escapes from a maximum-security forensic hospital and psychopathy. J Am Acad Psychiatry 1997;25:547-50

28. Moore E, \& Hammond S. When statistical models fail: problems in the prediction of escape and absconding behaviour from high-security hospitals. J Forensic Psychiatr Psychol 2000; 11(2):359-71

29. Rowley J, Slack F. Conducting a literature review. Manag Res News 2004;27(6):31-9

30. Hannes K, Lockwood C, Pearson A. A comparative analysis of three online appraisal instruments' ability to assess validity in qualitative research. Qual Health Res 2010;20(12):1736-43

\section{Corresponding author}

Ivana Furimsky, Forensic Psychiatry Program, St. Joseph's Healthcare Hamilton, Hamilton ON L9C 0E3, Canada - email: ifurimsk@stjosham.on.ca 